\title{
Perancangan dan Implementasi Self Assessment Untuk Sertifikasi ISO 9001:2015 Menggunakan Metode Baldrige Scoring
}

\author{
Benedictus Rahardjo ${ }^{1}$ \\ ${ }^{1}$ Fakultas Teknologi Industri, Program Studi Teknik Industri, \\ Universitas Kristen Petra. Jl. Siwalankerto 121-131, Surabaya 60236. \\ beni@petra.ac.id
}

Dikirimkan: 09, 2018. Diterima: , 04, 2019. Dipublikasikan:05, 2019.

\begin{abstract}
X company is a kind of service company in the plating area. The aim of this research is designing a self-assessment checklist regarding to the requirement of ISO 9001:2015 quality management. Actually, this company has implemented the ISO 9001:2015, however they never did the internal audit. In the purpose of doing the internal audit, it needs a self-assessment checklist to help each department in recognizing their lack of document. The checklist is made based on the requirement of clause 4 until 10 in ISO 9001:2015. The scoring category in the checklist is modified based on Baldrige scoring in process and result dimension. The result of this research is the gap analysis presented from clause 4 until 10 in percentage, which are 68,57\%, $80 \%, 64,44 \%, 80 \%, 71,6 \%, 82,67 \%$, and $55,56 \%$, respectively.
\end{abstract}

Keywords: Quality Management System, ISO 9001:2015, Baldrige Scoring

\begin{abstract}
Abstrak - Perusahaan X adalah sebuah perusahaan yang bergerak di bidang jasa pelapisan logam (plating). Penelitian ini bertujuan untuk perancangan checklist self-assessment terkait dengan kepentingan untuk melengkapi persyaratan sistem manajemen mutu ISO 9001:2015. Perusahaan ini sebenarnya telah menerapkan ISO 9001:2015, akan tetapi belum pernah melakukan audit internal. Dalam rangka melakukan audit internal, maka dibutuhkan sebuah checklist self-assessment untuk membantu tiap departemen mengetahui kekurangan dokumen yang ada. Dalam penelitian ini dirancang sebuah checklist self-assessment yang berdasarkan persyaratan klausul 4 hingga klausul 10 sesuai dengan sistem manajemen mutu ISO 9001:2015. Pada checklist ini, kategori penilaian yang digunakan adalah modifikasi dari kategori penilaian Baldrige pada dimensi proses dan hasil. Hasil dari penelitian ini diperoleh persentase analisa gap dari klausul 4 hingga klausul 10, berturut-turut adalah 68,57\%, 80\%, 64,44\%, 80\%, 71,6\%, 82,67\%, 55,56\%.

Kata kunci: Sistem Manajemen Mutu, ISO 9001: 2015, Penilaian Baldrige
\end{abstract}

\section{PENDAHULUAN}

Dalam era persaingan bisnis yang semakin ketat, setiap perusahaan dituntut untuk dapat bersaing dan menghasilkan produk atau jasa yang berkualitas baik. Produk atau jasa yang memiliki kualitas baik tergantung dari sistem manajemen mutu yang diterapkan dalam perusahaan tersebut. Sistem manajemen mutu yang diakui secara internasional adalah ISO 9001. ISO 9001 merupakan standar yang berisi persyaratan untuk sistem manajemen mutu yang dapat membantu perusahaan dalam hal meningkatkan efisien dan kualitas pelayanan.

Perusahaan X merupakan salah satu perusahaan yang bergerak dalam bidang industri jasa yang bekerja dalam jasa pelapisan logam (plating). Salah satu langkah yang dilakukan perusahaan ini ialah dengan mendapatkan sertifikasi ISO 9001:2015 dan menerapkan ISO 9001:2015 sebagai sistem manajemen mutu untuk meningkatkan efisien dan kualitas layanan pada perusahaan X. Salah satu cara untuk dapat mengetahui penerapan sistem manajemen mutu perusahaan sudah sesuai atau tidak, maka diperlukan evaluasi dalam bentuk pengukuran kinerja perusahaan yang dilakukan dengan cara melakukan audit internal perusahaan.

Audit internal maupun audit eksternal merupakan salah satu cara untuk dapat mengetahui penerapan ISO 9001:2015. Selain itu, untuk melakukan audit internal dan eksternal diperlukan waktu dan sumber daya manusia yang banyak. Audit internal dilakukan di perusahaan pada umumnya dengan melakukan audit antar departemen sehingga dibutuhkan waktu yang banyak dan dapat menggangu jadwal produksi. Manajemen perusahaan $\mathrm{X}$ masih belum 
mempunyai komitmen yang kuat dalam penerapan ISO 9001: 2015, khususnya audit internal.

Selain audit internal antar departemen, pengukuran kinerja Sistem Manajemen Mutu 9001:2015 dapat dilakukan dengan cara audit internal melalui self-assesment untuk setiap departemen yang ada dalam perusahaan.

Rancangan self-assessment harus dirancang sesuai, agar akurasi penilaian dari self-assessment juga sesuai dengan yang terjadi. Akurasi penilaian dari hasil self-assessment sangat penting, karena mempengaruhi penerapan ISO 9001:2015. Akurasi penilaian self-assessment yang tidak sesuai akan memberikan hasil yang tidak sesuai dan kurang akurat, selain itu waktu yang dibutuhkan bertambah untuk mengecek kembali akurasi penilaiannya dan jadwal produksi yang bisa terganggu, sehingga akurasi penilaian dari self-assessment ini sangat penting dan membantu perusahaan X dalam penerapan ISO 9001:2015.

Akurasi penilaian dari self-assessment juga ditentukan dari keahlian atau standar dari seseorang yang melakukan audit. Standar untuk seseorang yang melakukan audit harus mempunyai keahlian dan pelatihan teknis yang memadai sebagai auditor, dan dapat mempertahankan mental dari segala hal yang berhubungan dengan perikatan dan independensi. Selain itu seorang auditor juga wajib menggunakan kemahiran professional yang dimiliki dengan cermat. Standar untuk auditor yang digunakan saat dilakukan audit sangat berpengaruh terhadap hasil dan akurasi penilaian audit, sehingga diperlukan seseorang auditor yang telah mendapat pelatihan dan berkompeten dibidangnya.

\section{Metodologi Penelitian}

Pada bagian ini akan dibahas mengenai metode-metode yang digunakan untuk menyelesaikan perancangan dalam penelitian ini. Sistem Manajemen Mutu ISO 9001:2015 digunakan sebagai dasar dari penelitian ini. Metode yang dgunakan untuk perancangan skoring pada penelitian ini berasal dari Baldrige Scoring

\section{Sistem Manajemen Mutu}

Sistem Manajemen Mutu adalah sebuah sistem yang dapat diterapkan sebuah perusahaan atau organisasi yang bertujuan untuk meningkatkan kepuasan pelanggan dan membantu perusahaan dalam menjaga kualitas mutu dari jasa atau barang. Definisi Sistem Manajemen Mutu adalah sekumpulan prosedur terdokumentasi dan praktek-praktek standar untuk manajemen sistem yang bertujuan menjamin kesesuaian dari suatu proses dan produk (barang/jasa) terhadap kebutuhan atau persyaratan itu ditentukan atau dispesifikasikan oleh pelanggan atau organisasi [1].

Tujuan dari Sistem Manajemen Mutu adalah menjamin kesesuaian dari suatu proses dan produk terhadap kebutuhan atau persyaratan tertentu dan memberikan kepuasan kepada konsumen melalui pemenuhan kebutuhan dan persyaratan proses dan produk yang ditentukan pelanggan dan organisasi [1].

\section{Pengukuran Kinerja}

Konsep kinerja adalah "perilaku nyata yang ditampilkan setiap orang sebagai prestasi kerja yang dihasilkan oleh karyawan sesuai dengan perannya dalam perusahaan"[2]. Pengertian lainnya menurut mengatakan bahwa pengertian kinerja adalah "penampilan, hasil karya personil baik kualitas, maupun kuantitas penampilan individu maupun kelompok kerja personil, penampilan hasil karya tidak terbatas kepada personil yang memangku jabatan fungsional maupun structural tetapi juga kepada keseluruhan jajaran personil di dalam organisasi'’ [3].

Untuk mengetahui tinggi rendahnya kinerja perusahaan maka diperlukan suatu pengukuran kinerja. Pengukuran kinerja dalam suatu perusahaan berfungsi untuk membandingkan kinerja perusahaan pada periode lalu dan periode yang akan datang. Pengukuran kinerja merupakan usaha memetakan strategi ke dalam tindakan pencapaian target tertentu. Pengertian pengukuran kinerja adalah "sebagai penentu secara periodik efektivitas operasional suatu organisasi, bagian organisasi, dan karyawan berdasarkan sasaran, standar dan kriteria yang telah ditetapkan sebelumnya"[4].

\section{Self Assessment (Penilaian Diri)}

Self Assessment merupakan suatu metode perencanaan untuk perbaikan, dan tidak bertujuan untuk mendapatkan penghargaan atau award. Sebuah organisasi yang ingin menggunakan self assessment tidak dapat mendapatkan hasil yang cepat, tetapi berfungsi dalam penerapan strategi untuk jangka panjang untuk mendorong adanya suatu perbaikan dan peningkatan yang berkelanjutan. Proses penilaian diri merupakan pendekatan yang efektif dan berkontribusi secara signifikan untuk memperbaiki hasil akhir atau output. Dengan demikian proses penilaian harus difokuskan ke efektivitas metode yang digunakan organisasi, bukan kepada kinerja pekerja.

Penilaian diri adalah tindakan memonitor tingkat pengetahuan sendiri, pembelajarannya, kemampuannya, pikirannya, tindakan dan strategi yang dipergunakan [5]. Dengan demikian self assessment mengakomodasi dan menyediakan evaluasi kinerja organisasi sehingga organisasi 


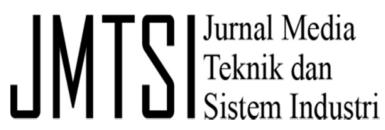

dapat membandingkan dan menganalisa pencapaian tujuan, strategi, dan tindakan-tindakan yang telah ditetapkan dan dilakukan. Serta dari penilaian dengan kriteria Malcolm Baldrige ini mampu mengidentifikasi kesenjangan (gap) antara produk yang dihasilkan dengan persyaratan dan harapan pelanggan yang terus berkembang, dan mengidentifikasi tahapan perubahan proses ke arah peningkatan yang berkelanjutan, termasuk menetapkan sistem dan mekanisme yang memungkinkan keunggulan kinerja organisasinya.

\section{Konsep Perancangan Checklist}

Perancangan adalah langkah pertama dalam fase pengembangan rekayasa produk atau sistem [6]. Perancangan merupakan suatu proses penerapan berbagai teknik dan prinsip yang bertujuan untuk mendefinisikan sebuah peralatan, proses, atau system secara detail yang membolehkan dilakukan realisasi fisik.

Konsep perancangan instrumen penelitian dijabarkan ke dalam enam langkah penyusunan [7], yaitu:

1. Mengidentifikasi variabel-variabel yang diteliti.

2. Menjabarkan variabel menjadi dimensidimensi.

3. Mencari indikator dari setiap dimensi.

4. Mendeskripsikan kisi-kisi instrumen.

5. Merumuskan item-item pertanyaan atau pernyataan instrumen.

6. Petunjuk pengisian instrumen.

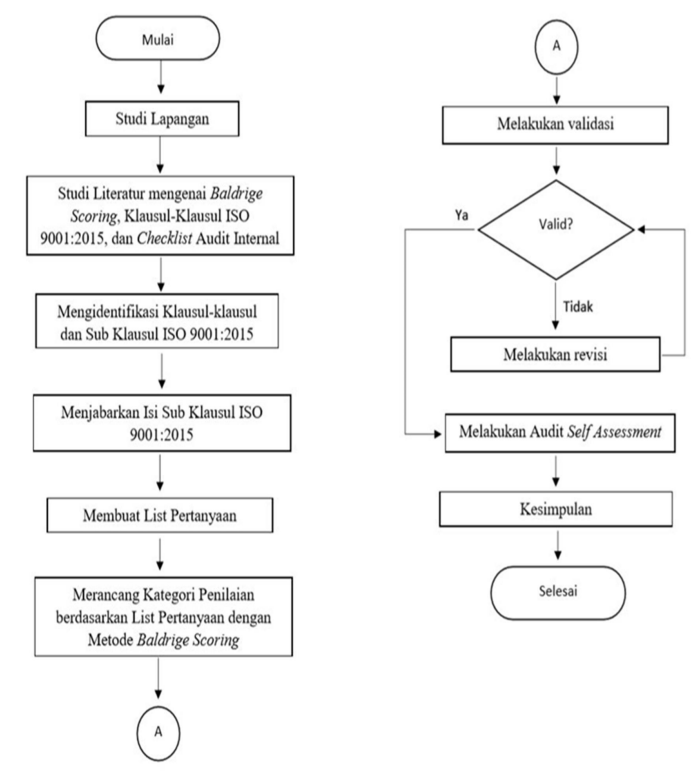

Gambar 1. Prosedur Penelitian

\section{HAsil PENELITIAN DAN PEMBAHASAN}

Pembahasan yang diulas dalam penelitian ini didasarkan dari identifikasi klausul-klausul ISO 9001:2015, yang terdiri dari klausul 1 sampai 3 yang merupakan klausul pembuka dan klausul 4 hingga 10 merupakan klausul isi. Pembahasan yang akan dibahas dalam jurnal ini yaitu hasil perancangan checklist self assessment dan kategori penilaian berdasarkan klausul 4 hingga 10, dan lebih berfokus pada klausul 4.1, 6.1 dan 6.2 .

\section{A. Identifikasi Klausul-Klausul ISO 9001:2015}

Klausul-klausul ISO 9001:2015 terdiri dari klausul 1 hingga klausul 10. Klausul 1 hingga klausul 3 merupakan klausul pembuka sedangkan klausul 4 hingga klausul 10 merupakan klausul isi. Identifikasi klausul ISO 9001:2015 yang dilakukan hanya pada klausul 4 hingga klausul 10. Hasil identifikasi klausul ISO 9001:2015 difokuskan pada klausul 4.1, 6.1, dan 6.2 adalah sebagai berikut:

- $\quad$ Klausul 4.1

Klausul 4.1 membahas mengenai bahwa setiap organisasi harus menentukan isu-isu eksternal dan internal yang sesuai dengan tujuan dan arah strategis organisasi dan yang mempengaruhi kemampuannya untuk mencapai hasil yang diinginkan dari sistem manajemen mutu. Cara untuk menentukan isu-isu eksternal dan internal, perusahaan $\mathrm{X}$ menggunakan analisa SWOT sebagai acuan untuk dijadikan strategi dan kebijakan perusahaan kedepannya. Analisa SWOT yang digunakan bertujuan untuk mengetahui kekuatan dan kelemahan perusahaan dari sisi internal perusahaan, selain itu juga untuk mengetahui peluang dan ancaman yang diberikan oleh perusahaan lain dari sisi eksternal perusahaan.

Analisa SWOT yang telah dibuat sebaiknya dilakukan analisa dari kenyataan yang ada di perusahaan untuk dijadikan dasar penentuan kebijakan. Hasil analisa SWOT perusahaan sebaiknya disimpan dan dipelihara untuk dilakukan monitor sesuai dengan ketetapan dari perusahaan.

\section{- $\quad$ Klausul 6.1}

Klausul 6.1 membahas mengenai penerapan mengenai analisa risiko dan peluang, dalam klausul ini juga meminta organisasi untuk mempelajari berbagai risiko dan peluang dengan mempertimbangkan isu-isu eksternal dan internal. Mempelajari risiko dan peluang dengan membuat 
activity plan (langkah perbaikan) bertujuan untuk mencegah dan mengurangi dampak dari risiko yang tidak diinginkan serta melakukan perbaikan berkelanjutan yang membuat sasaran sistem manajemen mutu tercapai. Penerapan analisa risiko dalam perusahaan juga harus sering dilakukan evaluasi secara rutin, dan juga prosedur untuk mengkomunikasikan analisa risiko yang telah dibuat ke setiap departemen yang ada dalam perusahaan. Selain itu penyimpanan dokumen untuk analisa risiko juga harus diperhatikan, karena analisa risiko dalam perusahaan dapat berganti-ganti seiring berjalannya waktu dan proses yang dilakukan.

\section{- $\quad \underline{\text { Klausul } 6.2}$}

Klausul 6.2 membahas mengenai persyaratan yang harus ditetapkan organisasi mengenai sasaran mutu, dimana sasaran mutu yang dibuat harus konsisten dengan manajemen mutu, terukur artinya memiliki target pencapaian, sesuai dengan persyaratan yang berlaku dan upaya pencapaian serta peningkatan kepuasan pelanggan. Dalam klausul ini juga mengisyaratkan agar sasaran mutu tidak hanya ditetapkan tetapi juga didokumentasikan, dipantau, dikomunikasikan, diperbaharui jika diperlukan dan direncanakan upaya untuk mencapainya. Pada klausul ini sebuah perusahaan diharuskan memiliki sasaran mutu yang didalamnya terdapat departemen terkait, strategi yang akan dipakai, target perusahaan, metode pengukuran, frekuensi pengukuran, sumber data, action plan.

\section{B. List Pertanyaan Checklist}

Pertanyan-pertanyaan yang dapat dimasukkan ke dalam checklist self assessment didasarkan dari hasil identifikasi, pertanyaan-pertanyaan tiap klausul yang dapat dimasukkan ke dalam checklist antara lain:

- $\quad$ Klausul 4.1

Klausul 4.1 dijabarkan menjadi 2 pertanyaan yang dapat dimasukkan ke dalam checklist self assessment, antara lain:

$>$ Apakah perusahaan telah melakukan identifikasi internal dan eksternal issue (SWOT) serta dianalisa sebagai dasar penentuan kebijakan ke depan?

$>$ Apakah perusahaan menyimpan bukti pembuatan dokumen internal dan eksternal issue (SWOT) serta dimonitor?

- $\quad$ Klausul 6.1

Hasil identifikasi klausul 6.1 dapat dijabarkan menjadi 3 pertanyaan yang dapat dimasukkan ke dalam checklist self assessment, antara lain:
> Apakah telah dibuat dan ditetapkan prosedur manajemen risiko dan telah disosialisasikan ke semua pihak terkait dan berkepentingan?

> Apakah telah dilakukan analisa risiko dan penentuan tindakan pada semua bisnis proses tiap departemen perusahaan?

> Apakah perusahaan menyimpan dokumen manajemen risiko dan menganalisa risiko dan peluang tindakannya dan dievaluasi secara periodik?

- Klausul 6.2

Hasil identifikasi klausul 6.2 dapat menghasilkan beberapa pertanyaan yang dapat dimasukkan ke dalam checklist self assessment, antara lain:

$>$ Apakah perusahaan pernah mengukur sasaran mutu? dipantau? dikomunikasikan ke tiap departemen? diperbaharui sesuai kebutuhan?

$>$ Apakah perusahaan telah membuat dan menetapkan sasaran mutu serta target dan proses yang dibutuhkan untuk sistem manajemen mutu?

> Apakah perusahaan menyimpan dokumen sasaran mutu dan dianalisa berkala serta dimonitor?.

\section{Perancangan Kategori Penilaian}

Perancangan kategori penilaian yang dilakukan berdasarkan kategori penilaian dari baldrige scoring. Penilaian dari baldrige scoring merupakan penilaian yang berbasis persentase, Tabel I adalah contoh baldrige scoring dalam dimensi proses yaitu approach atau pendekatan.

TABEL I

\begin{tabular}{|c|c|c|}
\hline \multicolumn{3}{|c|}{ BALRIDGE SCORING } \\
\hline Skor Modifikasi & Baldrige Scoring & Penjelasan \\
\hline 1 & $0-5 \%$ & $\begin{array}{l}\text { Tidak ada } \\
\text { pendekatan } \\
\text { sistematis untuk } \\
\text { persyaratan } \\
\text { barang yang jelas; } \\
\text { informasi bersifat } \\
\text { anekdot. }\end{array}$ \\
\hline \multirow[t]{2}{*}{2} & $10-20 \%$ & $\begin{array}{l}\text { Permulaan } \\
\text { pendekatan } \\
\text { sistematis } \\
\text { terhadap } \\
\text { kebutuhan dasar } \\
\text { barang adalah } \\
\text { jelas. } \\
\end{array}$ \\
\hline & $30-45 \%$ & $\begin{array}{l}\text { Pendekatan yang } \\
\text { efektif } \\
\text { sistematis, } \\
\text { responsif terhadap } \\
\text { kebutuhan dasar }\end{array}$ \\
\hline
\end{tabular}




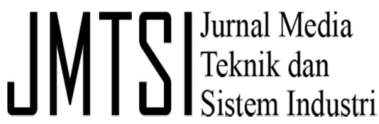

\begin{tabular}{|c|c|c|}
\hline & & barang, terbukti. \\
\hline 3 & $50-65 \%$ & $\begin{array}{l}\text { Pendekatan yang } \\
\text { efektif dan } \\
\text { sistematis, } \\
\text { responsif terhadap } \\
\text { kebutuhan dasar } \\
\text { barang, terbukti. }\end{array}$ \\
\hline 4 & $70-85 \%$ & $\begin{array}{l}\text { Pendekatan yang } \\
\text { efektif dan } \\
\text { sistematis, } \\
\text { responsif terhadap } \\
\text { berbagai } \\
\text { persyaratan } \\
\text { barang, terbukti. }\end{array}$ \\
\hline 5 & $90-100 \%$ & $\begin{array}{l}\text { Pendekatan yang } \\
\text { efektif dan } \\
\text { sistematis, } \\
\text { sepenuhnya } \\
\text { responsif terhadap } \\
\text { keseluruhan } \\
\text { kebutuhan barang, } \\
\text { terbukti. }\end{array}$ \\
\hline
\end{tabular}

- $\quad$ Kategori Penilaian Klausul 4.1

Kategori penilaian pada klausul ini berdasarkan dari penerapan analisa SWOT, strategi, dan kebijakan perusahaan. Matriks yang digunakan dalam kategori penilaian ini dapat dilihat pada Tabel II.

TABEL II

MATRIKS PENILAIAN KLAUSUL 4.1

\begin{tabular}{|c|c|c|c|c|c|c|}
\hline \multirow{2}{*}{ SK } & \multicolumn{6}{|c|}{ Kelengkapan Dokumen Perusahaan (SWOT- } \\
\cline { 2 - 7 } OR & $\begin{array}{c}\text { Stre } \\
\text { ngth }\end{array}$ & $\begin{array}{c}\text { Weak } \\
\text { ness }\end{array}$ & $\begin{array}{c}\text { Oppurt } \\
\text { unities }\end{array}$ & $\begin{array}{c}\text { Thr } \\
\text { eat }\end{array}$ & $\begin{array}{c}\text { Stra } \\
\text { tegi }\end{array}$ & $\begin{array}{c}\text { Kebij } \\
\text { akan }\end{array}$ \\
\hline 1 & - & - & - & - & - & - \\
\hline 2 & v & v & - & - & - & - \\
\hline 3 & v & v & v & v & - & - \\
\hline 4 & v & v & v & v & v & - \\
\hline 5 & v & v & v & v & v & v \\
\hline
\end{tabular}

- $\quad$ Kategori Penilaian Klausul 6.1

Kategori penilaian yang dilakukan pada klausul ini dapat dilihat pada matriks penilaian yang terdapat pada Tabel III.

TABEL III

MATRIKS PENILAIAN KLAUSUL 6.1

\begin{tabular}{|c|c|c|c|c|c|}
\hline \multirow{2}{*}{ SK } & \multicolumn{5}{|c|}{ Kelengkapan Pembuatan Dokumen Analisa } \\
OR & $\begin{array}{c}\text { Potensi } \\
\text { Kegaga } \\
\text { lan }\end{array}$ & $\begin{array}{c}\text { Damp } \\
\text { ak }\end{array}$ & $\begin{array}{c}\text { Penye } \\
\text { bab }\end{array}$ & $\begin{array}{c}\text { Pember } \\
\text { ian } \\
\text { Nilai }\end{array}$ & $\begin{array}{c}\text { Activ } \\
\text { ity } \\
\text { Plan }\end{array}$ \\
\hline 1 & - & - & - & - & - \\
\hline 2 & v & v & - & - & - \\
\hline 3 & v & v & v & - & - \\
\hline 4 & v & v & v & v & - \\
\hline 5 & v & v & v & v & v \\
\hline
\end{tabular}

- Kategori Penilaian Klausul 6.2

Kategori penilaian yang dilakukan pada klausul ini dapat dilihat pada matriks penilaian yang terdapat pada Tabel IV.

TABEL IV

MATRIKS PENILAIAN SASARAN MUTU

\begin{tabular}{|c|c|c|c|c|c|c|}
\hline \multirow[b]{2}{*}{$\begin{array}{l}\mathrm{S} \\
\mathrm{K} \\
\mathrm{O} \\
\mathrm{R}\end{array}$} & \multicolumn{6}{|c|}{ Sasaran Mutu Perusahaan } \\
\hline & $\begin{array}{c}\text { Mem } \\
\text { buat }\end{array}$ & $\begin{array}{l}\text { Menet } \\
\text { apkan }\end{array}$ & $\begin{array}{c}\text { Dikomu } \\
\text { nikasika } \\
\mathrm{n}\end{array}$ & $\begin{array}{c}\text { Penera } \\
\text { pan }\end{array}$ & $\begin{array}{l}\text { Penyimp } \\
\text { anan } \\
\text { Dokumen }\end{array}$ & $\begin{array}{c}\text { Activi } \\
\text { ty } \\
\text { Plan }\end{array}$ \\
\hline 1 & - & - & - & - & - & - \\
\hline 2 & $\mathrm{v}$ & $\mathrm{v}$ & - & - & - & - \\
\hline 3 & $\mathrm{~V}$ & $\mathrm{~V}$ & $\mathrm{~V}$ & - & - & - \\
\hline 4 & $\mathrm{~V}$ & $\mathrm{~V}$ & $\mathrm{~V}$ & $\mathrm{~V}$ & - & - \\
\hline 5 & $\mathrm{~V}$ & $\mathrm{~V}$ & $\mathrm{~V}$ & $\mathrm{~V}$ & $\mathrm{~V}$ & $\mathrm{~V}$ \\
\hline
\end{tabular}

- Kategori Penilaian Klausul Secara Umum

Kategori penilaian secara umum ini digunakan untuk klausul-klausul diluar dari klausul 4.1, 6.1, dan 6.2. Tabel V merupakan kategori penilaian secara umum yang dapat digunakan dalam peneilitian ini.

TABEL V

KATEGORI PENILAIAN SECARA UMUM

\begin{tabular}{cl}
\hline Nilai & \multicolumn{1}{c}{ Keterangan } \\
\hline 1 & $\begin{array}{l}\text { Perusahaan belum membuat atau menerapkan } \\
\text { atau menentukan atau merancang sistem atau } \\
\text { dokumen. }\end{array}$ \\
\hline 2 & $\begin{array}{l}\text { Perusahaan sedang membuat atau menerapkan } \\
\text { atau menentukan atau merancang sistem atau } \\
\text { dokumen. }\end{array}$ \\
\hline 3 & $\begin{array}{l}\text { Perusahaan sudah membuat atau menentukan } \\
\text { sistem atau dokumen. }\end{array}$ \\
\hline 4 & $\begin{array}{l}\text { Perusahaan sudah membuat dan memiliki dan } \\
\text { menentukan dan menerapkan sistem atau } \\
\text { dokumen. }\end{array}$ \\
\hline 5 & $\begin{array}{l}\text { Perusahaan sudah membuat dan memiliki dan } \\
\text { menentukan dan menerapkan sistem atau } \\
\text { dokumen dan dianalisa dan dievaluasi serta } \\
\text { dokumennya dikendalikan atau dimonitor. }\end{array}$ \\
\hline
\end{tabular}

\section{KESIMPULAN}

Hasil perancangan checklist self assessment ini dibuat berdasarkan klausul-klausul yang terdapat pada ISO 9001:2015. Klausul-klausul yang dimasukkan ke dalam perancangan checklist self assessment merupakan klausul isi yaitu klausul 4 sampai klausul 10.

Dengan adanya rancangan checklist self assessment ini juga membantu sebuah perusahaan untuk melakukan pengecekan dan memonitor kekurangan-kekurangan yang dimiliki sebuah perusahaan. Rancangan checklist self assessment ini membantu perusahaan untuk menentukan tindakan 
yang akan diambil untuk memperbaiki dan meningkatkan kinerja perusahaan sebelum dilakukan audit eksternal.

Penerapan checklist self assessment dari klausul 4 sampai klausul 10 memiliki jumlah total pertanyaan sebanyak 120 yang dibagi secara berturut-turut tiap klausul adalah 7, 11, 9, 19, 50, 15 dan 9 pertanyaan sedangkan hasil penerapan dari checklist self assessment didapatkan nilai tiap klausul berturut-turut adalah 24, 44, 76, 179, 64, 25. Persentase yang didapatkan dari tiap klausul hasil penerapan secara berturut-turut adalah $68,57 \%, 80 \%, 64,44 \%, 80 \%, 71,6 \%, 82,67 \%$, $55,56 \%$.

\section{REFERENSI}

[1] Gaspersz, V. ISO 9001:2000 and continual quality improvement. Jakarta: PT. Gramedia Pustaka Utama. 2002

[2] Rivai, V. Manajemen sumber daya manusia untuk perusahaan, dari teori Ke Praktek. Jakarta: PT. Rajagrafindo Persada. 2005

[3] Yaslis, I.. Kinerja, teori dan penelitian. Yogyakarta : Liberty. 2005

[4] Mulyadi \& Setyawan, J. Sistem perencanaan dan pengendalian manajemen, Edisi 2. Jakarta : Salemba Empat.. 2007

[5] Wilson, J. \& Leslie W. J. Self-assessment for students. Proformas and guidelines. Armadale: Eleanor Curtain Publishing. 1998

[6] Pressman, R. S. Software engineering: A Practitioner's approach. New York: McGrawHill. 2010

[7] Iskandar. Metodologi penelitian pendidikan dan sosial (kualitatif dan kuantitatif). Jakarta: Garuda Persada Press. 2008 